\title{
ANALYSIS OF FOOD SECURITY STATUS OF FARMING HOUSEHOLDS IN THE FOREST BELT OF THE CENTRAL REGION OF GHANA
}

\author{
John K.M. Kuwornu, Demi M. Suleyman, Ditchfield P.K. Amegashie, Researchers \\ Department of Agricultural Economics and Agribusiness \\ University of Ghana, Legon-Accra, Ghana \\ E-mail: jkuwornu@gmail.com
}

\begin{abstract}
The study seeks to examine the Food Security Status of Farming Households in the Forest Belt of the Central Region of Ghana. A multistage sampling technique was used to select the respondents that were interviewed. In all 134 farming households were interviewed but 120 were selected for analysis after removing the questionnaires which were not properly administered. The households were selected from eight communities in two districts. Food consumption data of 851 individuals in 120 households were used for the analysis. The study reveals that the majority of the farming households (60\%) were found to be food insecure. Further, the Binary Logit Model results reveal that an increase in household's income, having access to credit as well as increase in the quantity of own farm production improve the food security status of farming households in the Forest Belt of the Central Region of Ghana. However, holding all other factors constant, increases in non-working member of households worsens the food security status of farming households. Most of the food insecurity coping strategies adopted by household's are not severe and can only be used to avert the impact of food insecurity on a temporal basis. These results have policy implications for Food Security Status of Farming Households in developing countries.
\end{abstract}

\section{KEYWORDS}

Farming Households; Food Security; Food Security Index; Logit Model; Forest Belt; Ghana.

Various interventions have been made by governments in modernizing agriculture in Africa which was previously characterized by sluggish growth, low factor productivity, declining terms of trade, and often linked to practices that degrade the environment (Salama et al., 2010). Since the late 1970s to mid-1980s, many African countries including Ghana have implemented macroeconomic policies, sectoral and institutional reforms aimed at ensuring high and sustainable economic growth, food security and poverty reduction. Though in recent times some African countries have recorded some level of growth in the agricultural sector, however, the sector's growth remained insufficient to adequately address poverty, attain food security, and lead to sustained GDP growth on the continent (Dessy et al., 2006 and World Bank, 2008). Food security and poverty reduction have been a major campaign issues across all political parties, yet provision of enough food to feed the entire population has eluded many governments.

Food is the basic need and necessity of life that must be satisfied before any other developmental issue. Inadequate nutrition is considered as measure of poverty in many societies or synonymous to poverty (Datt et al., 2000). Helen (2002) noted, food security maintains political stability, and ensures peaceful coexistence among people while food insecurity results in poor health and reduced performance of both children and adult. Food security is therefore defined "as a situation when all people, at all times, have physical and economic access to sufficient, safe and nutritious food to meet their dietary needs and food preferences for a healthy and active life" (FAO, 1996).

Ironically, farming households are the most affected in terms of food insecurity and poverty in Africa especially the smallholder farming households though the rest of the population depends on their production. According to Cruz (2010) and Valdés et al., (2010), majority (more than 80 per cent) of the smallholder farmers in the world are food insecure and depend on land as their primary source of livelihoods. Three out of every four poor people leave in rural areas and depend on agriculture either directly or indirectly for their livelihood (World Bank, 2008). 
In most part of the world and especially in the developing countries, concerns regarding food security and its related issues are vital for poverty reduction. Attainment of food security is core problem confronting farming households, especially women and rural populations due to low productivity in staple crop production, seasonal variability in food supply as well as price fluctuations. These problems facing farming households come about as a result of overreliance on rain-fed agriculture, none or inappropriate usage of chemical inputs as well as inadequate improved varieties of crops and animal species. Food security of farming households is of serious concern if Ghana wants to consolidate her macroeconomic gains because; farmers who are vulnerable to food and nutritional insecurity have limited capacity to respond to agricultural programmes.

Despite the fact that Ghana made significant achievement towards meeting the millennium development goal one by halving poverty from approximately 51.7 per cent in 1991-1992, to 28.5 per cent in 2005-2006 (Ghana Statistical Service (GSS), 2008); the depth of poverty has exacerbated and spread into urban areas (WFP, 2009). Farming households were recognized as most affected by poverty among all the economic activities with almost half of them (46\%) falling below the poverty line (WFP, 2009). According to the statistics of World Food Programme (2009), about 1.2 million people, representing 5\% of the population of Ghana are food insecure and 2 million people are vulnerable to become food insecure in an event of any natural or man-made shock.

Recent surge in world food prices, changing climatic pattern resulting in global warming as well as growing demand for arable land for cultivation of biofuel has worsen the food security situation in most part of the world especially developing countries and Ghana cannot be exempted from these current development. Ghana is only self-sufficient in the production of root and tubers, though production is erratic and fluctuates between scarcity, sufficiency and glut depending on the quirks of weather, (Ministry of Food and Agriculture (MoFA), 2007). Ghana has high deficit in the production of cereals, meat and fish even though Kuwornu et al., (2011) noted that cereals are the most widely consumed food crop in Ghana.

Ghana produces $51 \%$ of its cereal needs, $60 \%$ of fish requirement, $50 \%$ of meat and less than $30 \%$ of the raw materials needed for agro-based industries (MoFA, 2007). Ghana had its fair share of global financial crisis which saw food prices soaring from 2006 in most part of the world. Food prices for rice, maize and other cereals increased in Ghana by 20 to 30 percent between the last few months of 2007 and the beginning of 2008 (Wodon et al., 2008). As result of the food price increases; $18 \%$ of the population whose income is less than the costs of the minimum food basket have become more vulnerable and less resilient to food insecurity (WFP, 2009).

The growing demand for arable land for biofuel cultivation is a serious threat to ensuring food security in Ghana since evidence in India and other part of the world indicate negative signals. Recent increases in the prices of energy worldwide has resulted in massive foreign investments in biofuel production and Ghana has been projected to be among the biggest producers of Jatropha in Africa by 2015 (IFAD and FAO, 2010). According to the CIA World Fact Book, Ghana has 3.99 million hectares of arable land with 2.075 million hectares under permanent crops cultivation (www.foodsecurityghana.com).

Out of the land under permanent cultivation (2.075 million ha) 769,000 hectares have been acquired by foreign companies for biofuel cultivation (www.foodsecurityghana.com). This means 37 percent of Ghana's cropland has been grabbed for the plantation of jatropha and in some cases, food crops have been cleared to plant jatropha, leaving farmers with no income and no source of food.

The changing climatic pattern and over reliance on rain-fed agriculture pose a serious food security challenge to Ghana. The United Nation estimate has projected that over the next 20 years demand for food will exceed 50\%. Ironically, Boko et al., (2007) revealed that yields from Africa's rain-fed farm production may decrease by $50 \%$ as result of changes in climatic conditions by 2020.

In the mist of this challenging statistics, the population of Ghana is growing at rate of 2.5 percent (3.5\% in Central Region) yet agricultural growth is fluctuating. Agricultural sector of the economy recorded a decline in growth rate from 5.3 in 2010 to 0.8 in 2011 (GSS, 
2012). The various sub-sectors in the area of crops, and fishing have recorded decline with only livestock appreciating marginally. For instance, the crop sub-sector which is key determinant of food security has declined for the three consecutive times from 10.2 in 2009 , 5.0 in 2010 to 3.7 in 2011(GSS, 2012). The growth rate of livestock also declined from 1.5 in 2010 to -8.7 which could affect the protein intake of households (GSS, 2012).

Available statistics indicate that economy of Ghana is doing well at the macro level making Ghana to be regarded as one of the fastest growing economy in the world. Equally worth noting are the following: high food prices, changing climatic patterns and growing demand for land for biofuel cultivation in Ghana. These situations which have made it necessary to examine the current food security status of farming households who are already trapped in poverty and where vast arable land is used for biofuel (jatropha) cultivation in the Forest belt of the Central Region of Ghana. Central Region is the fifth poorest regions in Ghana. These developments coupled with the recent high food prices have serious implications on the food security status of the region making it one of the vulnerable regions to food insecurity in Ghana. However, most of food security studies conducted in Ghana are concentrated in the three northern regions considered the poorest. The few studies on the Central Region examined the effects of biofuel cultivation on household food security. Much has not been done in analyzing the food security status of farming households who are the most food insecure population.

Therefore, objectives of the study are threefold: First, to establish the food security status of farming households in the forest belt of Central Region of Ghana; Second, to determine the factors influencing food security status of farming households in the study area; Third, to identify and rank food insecurity coping strategies used by farming households in the study area.

\section{LITERATURE REVIEW}

The term "food security" gained prominence after the World Food Conference in 1974 and ever since has become households name and attracted so many definitions from various organizations and individual researchers. Food security is defined as "access by all people at all times to enough food for an active and healthy life" (World Bank, 1986 p.8). This definition provided a standard for further definitions and addresses the issues of availability, accessibility, as well as utilization of food for healthy living. The World Bank (1986) definition was subsequently augmented by FAO to include the nutritional value and food preferences.FAO, (1996) defined food security as a situation when all people, at all times, have physical and economic access to sufficient, safe and nutritious food to meet their dietary needs and food preferences for a healthy and active life.

The inclusion of "safe and nutritious" stresses food safety and nutritional composition whiles the addition of food preferences" changes the concept of food security from mere access to enough food, to access to the food preferred. However, the operational definition for food security by Ministry of Food and Agriculture in Ghana is "good quality nutritious food hygienically packaged, attractively presented, available in sufficient quantities all year round and located at the right place at affordable prices" (MoFA, 2007 PP.24). Food security was formerly assumed as adequacy of food supply at the global and national levels until the mid 1970 's. This view only takes into account food production oriented variables and overlooked the multiple forces which come to play to affect access of food.

Large amount of food at global level does not guarantee food security at national level. Furthermore, availability of enough food at national level does not necessarily ensure household food security. For example UNDP (1992) noted that calorie supply at global level in 1990 was over 110 percent compared to the total requirement. Yet in the same period, more than quarter of the world's population was short of enough food (UNDP, 1992).

When an individual or population lacks, or is potentially vulnerable due to the absence of, one or more factors outlined in the above definition, then it suffers from, or is at risk of becoming food insecure. The inclusion of stability of food supply, and food and nutrition safety in the definition of food security (MoFA, 2007; USAID, 2008) has added additional 
dimensions to food security. Jradet al., (2010), elaborated on five dimensions of food security as food availability, food accessibility, food utilization, stability of food supply and food and nutrition safety.

Food Availability refers to the physical presence of food which may come from own production, purchases from internal market or import from overseas. Gregory et al., (2005) explained that food availability refers to the existence of food stocks for consumption.

Food Access. Household food access is the ability to obtain sufficient food of guaranteed quality and quantity to meet nutritional requirements of all household members. Here, the food should be at right place at the right time and people should have economic freedom or purchasing power to buy adequate and nutritious food. Kuwornu et al., (2011), explained that food access is determined by physical and financial resources, as well as by social and political factors.

Food Utilizatio. This refers to ingestion and digestion of adequate and quality food for maintenance of good health. This means proper biological use of food, requiring a diet that contains sufficient energy and essential nutrients, as well as knowledge of food storage, processing, basic nutrition and child care and illness management.

Stability of Food Supply: This refers to the continuous supply of adequate food all year round without shortages. In the mist of growing population, unfavourable climatic patterns and growing demand for biofuel use; constant supply of food will depend on improved productivity and availability of proper storage facilities. Means of distribution of food required improvement through provision of motorable roads to food growing areas. The use of storage van here will be a key element to prevent post-harvest losses to sustain the interest of farmers to grow more to feed the population.

Food and Nutrition Safety. Food safety is part of a wide range of issues which go beyond the avoidance of food-borne biological pathogens, chemical toxicants, and other hazards (FAO, 2002). There is growing concern of consumers of developed countries about the effects of the food they eat on their health. Consumers expect food not only to meet their nutritional needs but also should be wholesome and tasty, and to be produced ethically respecting the environment, animal health and welfare. This, however, is not a priority in developing countries where the major concerns are access and availability of a nutritious diet throughout the year at relatively low costs (FAO, 2002). Developing countries are forced to overlooked food safety due to high poverty and illiteracy rate.

Food safety constitutes an effective platform for poverty alleviation, social and economic development, while opening and enlarging opportunities for trade. However, ensuring food safety comes with a cost, and excessive food safety requirements may impose constraints on production, storage and distribution systems, which may possibly result in trade barriers or impede competitiveness (FAO, 2002).

National food security was used to describe whether a country had access to enough food to meet dietary energy requirements of her citizens. To some it connotes selfsufficiency, which means a country produces enough food to meet its population's demand. But broadly, national food security measures the extent to which a country has the means to make available to its people the food needed or demanded, irrespective of whether the food is domestically produced or imported (Pinstrup-Andersen, 2009). Food insecurity is the absence of food security and applies to a wide range of phenomena ranging from famine to periodic hunger to uncertain food supply (Bokeloh et al., 2009). Food Insecurity is the inability of a household or individuals to meet their daily required food consumption levels in the face of fluctuating production, food price and income (Moharjan and Chhetri, 2006). Food insecurity is therefore caused by various factors some of which are multifaceted.

The major single factor responsible for food insecurity in developing and less develop countries has been the high poverty rate among the population. Poverty has become endemic in Africa and continues to resist efforts aimed at eradicating it (Arimah, 2004). According to Arimah (2004), fifteen (15) out of the world twenty (20) identified poorest countries are in Africa. The poverty in Africa has been compounded by conflicts and civil war, political instability, droughts, high external debt and by the rapid rise and spread of HIV/AIDS. UNDP (1997) defined poverty "as the result of the deprivation of basic capabilities, 
which leads to reduced life expectancy, health, participation, personal security, environmental degradation, as well as the absence of real opportunities to lead a valuable life and valued life".

Several studies have found nutritional status measured through energy and protein intake as one major indicator of poverty (Srinivasan, 1988; Datt and Jolliffe, 1999; Datt et al., 2000). Other criteria used to identify the poor in the society are household income (Sen, 1976; Sadeghi et al., 2002), employment (Fofack, 2002), asset holdings (Grootaert, 1997; Geda et al., 2001) and food consumption expenditures (Greer and Thorbecke, 1986; Fofack, 2002).

Meeting the food needs of families in Sub-Saharan Africa remains a serious challenge. This challenge emerges due to widespread poverty and conflict (Misselhorn, 2005; Smith et al., 2000; Oldewage-Theron et al., 2006); drought, famine and other negative weather patterns exacerbated by global climate change (Rosenzweig et al., 2001); degradation and deforestation (Baro and Deubel, 2006), increased food prices due to the growth in demand for biofuels (Trostle, 2008) and low agricultural productivity (Haile, 2005). Combination of these factors restricts access to food for many in developing countries.

Ghana has been fairly stable in terms of food security on national basis, although, some pockets of food insecurities situations have been recorded in some areas particularly in the three northern regions. Africa has witnessed severe droughts in 1970, 1983 and 1984 in the past four decades where between 24 to 30 countries were affected. However, the 1983 and 1984 droughts were the most severe causing wide spread famine in Africa requiring massive humanitarian food aid (Haile, 2005).

Ghana was hardly affected by 1983 drought where acute food shortage was recorded and this saw people depending on all kinds of material for survival. Among the food consume during this period includes cocoyam comb, rhizome of bamboo, water leafs and unripe bananas were substituted for plantain which under normal circumstances were not part of Ghanaian foodstuff. According to Ghana Statistical Service (2008), about $18.2 \%$ of Ghanaians who fall below the extreme poverty line are chronically food insecurity. Also about $10.3 \%$ of those above the extreme poverty line but classified as poor are vulnerable to food insecurity depending on the whims of the weather (MOFA, 2010). However, most of the food security situations in Ghana are more cyclical in nature and are recorded in all the ten regions but Upper East Region, for example is the most vulnerable to transient food insecurity.

Statistics available suggest that the prevalence rate of malnutrition among children below the age of five, and women of reproductive age is still high. It states, $22 \%$ of children are stunted or too short for their age, $7 \%$ of children are too thin for their height (WFP, 2009).

The Government of Ghana through the Ministry of Food and Agriculture is embarking on various interventions to revert the situation. Notable among the interventions are fertilizer subsidy which allow farmers to access fertilizer at reduced prices and also provision of livestock to selected farmers to serve as out growers. The farmers then returned the offspring of the livestock collected to be given to other farmers in order to expand the scheme. Though the interventions are commendable, they are faced with several challenges. For instance, the fertilizer subsidy comes too late, sometimes several months after farmers have planted their crops hence less effective on the crops.

Selection of committed farmers has been a major setback to the livestock improvement programme. In most cases farmers selected are perceived to be aligned to particular political parties leading to over politicization of the selection processes. This results in distribution of the livestock to political cronies rather than committed and experienced farmers. This has made the programme less effective and not visible to many.

\section{METHODOLOGY}

General background to the methodology. Several methods have been used by researchers to establish food security status of households, but notable among them are Cost-of-calorie approach and Food Security index approach. Oluyole et al., (2009), examined 
the food security status among cocoa farming households of Ondo State, Nigeria and employed Cost-of Calorie (COC) function proposed by Greer and Thorbecke (1986). This method was also used in similar studies (Ojogho, 2010; Adenegan and Adewusi, 2007). The function is stated as:

$$
\ln h=a+b C(1)
$$

where $h$ denotes food expenditure; $C$ denotes calorie consumption (Kcal). From the COC function, the Cost of minimum recommended energy level, $Z$ was calculated as: $Z=e^{(a+b L)}$, where L denotes Recommended Daily Energy Level (Kcal); $a$ is the intercept term; $b=$ coefficient of the calorie consumption. Based on the estimation, a household whose average cost of daily calorie consumption is equal to or more than $Z$ is said to be food secure while a household with average cost of daily calorie consumption lower than $Z$ is considered food insecure. The surplus/shortfall was estimated using the function:

$$
P=\frac{1}{N} \sum_{j=1}^{m} G_{j}
$$

$$
G_{j} \text { is expressed as: }\left(X_{i}-L\right) / L \text {, }
$$

where $P$ denotes Surplus/Shortfall, $L$ denotes Recommended Daily Per Capita Requirement $(2,450 \mathrm{Kcal}) ; G_{j}$ Calorie faced by household, $X_{i}$ Per Capita Food Consumption Available to household and $N$ denotes Number of households that are food secure (for surplus index) or food insecure (for shortfall index).

Babatunde et al., (2007) and Omotesho et al., (2010), examined the socio-economic characteristic of household in Kwara State, Nigeria, using food security index to determine the food security status of each household based on the Recommended Daily Calorie approach. This method (Food Security Index) was also used by several researchers (KhatriChhetri and Maharjan, 2006; Omotesho et al., 2006, Arene and Anyaeji, 2010). Household whose food security index is greater or equal to the Recommended Daily Calorie Intake were regarded as food secure and those whose food security index is lower than the recommended Daily Calorie Intake $(2260 \mathrm{Kcal})$ were considered food insecure. The method is outlined in details latter on in this section.

Literature has also provided various models for determining factors influencing food security status of households and key among them as used by researchers are Tobit model (Etim and Solomon, 2010), Probit model (Oluyole et al., 2009) and Logit model as used by Babatunde et al.,(2007). However, the study used Logit model due to its simplicity in the interpretations of the coefficients. The dependent variable in this case, food security status, is a binary variable which takes a value of one (1) for food secured household and zero (0) for food insecure household. The cumulative logistic probability model was specified by Pindyck and Rubinfeld, (1981) as:

$$
P_{i}=F\left(Z_{i}\right)=1+\frac{1}{1+e^{-\left(\alpha+\sum \beta_{i} x_{i}\right)}}(3)
$$

where $P_{i}$ is the probability that an individual is being food secure given $X_{i}$ (the explanatory variables); $a$ and $\beta_{i}$ are parameters to be estimated. The log odds of the probability that an individual is being food secure is given by:

$$
\log \left(\frac{p_{i}}{1-p_{i}}\right)=Z_{i}=\alpha+\beta_{1} x_{1}+\beta_{2} x_{2}+\ldots \ldots+\beta_{k} x_{k}
$$


Various methods for testing ranking of an object have been identified from literature and notable among them are Garrett's ranking score techniques, Friedman's two-way analysis of variance and Kendall's coefficient of concordance. There is close relation between Friedman's test and Kendall's coefficient of concordance (Legendre, 2005). They address hypotheses concerning the same data and use Chi squarer test for testing. However, they differ in the formulation of their respective hypothesis. Whereas Friedman's test focuses on the items being ranked, the hypothesis of Kendall's test focuses on the rankers themselves.

Garrett's ranking score techniques on the other hand uses average score of the rankers and arrange them in either ascending or descending order. However, the limitation of this method is that it involves a number of steps and it does not test the level of agreements between rankers. Kendall's coefficient of concordance was employed by this study because the Kendall's $(W)$ provides the test of agreement of the rankers (respondents), among their rankings which the Friedman's and Garrett's test lacks.

Estimating Food Security Index. To establish food security status of farming households in the study area, the study constructed Food Security Index $\left(Z_{i}\right)$ and determined the food security status of each household based on the food security line using the Recommended Daily Calorie Required approach as used by Babatunde et al., (2007). Households whose Daily Calorie Intake were equal or higher than Recommended Daily Calorie Required were considered food secure households and those whose Daily Calorie Intake were below the Recommended Daily Calorie Required were considered food insecure households. The Food Security Index is given as:

$$
Z_{i}=\frac{Y_{i}}{R}(5),
$$

where $Z_{i}$ represents Food Security Index of $\mathrm{i}^{\text {th }}$ household, $Y_{i}$ is Actual Daily Calorie Intake of $i^{\text {th }}$ households and $R$ is the Recommended Daily Calorie Requirement of $i^{\text {th }}$ household. To obtain Per Capita Daily Calorie Intake; daily calorie intake of each household was divided by its' household size. Households' Per Capita Daily Calorie Requirement was also obtained by dividing the households' Daily Calorie Requirement by household size. Based on the food security index estimated, the study further estimated other indices such as food insecurity gap (FIG), headcount ratio (HCR) and Surplus Index (SI). Food Insecurity gap is given by:

$$
\frac{1}{M} \sum_{i=1}^{n} G_{i}(6),
$$

where $M$ represents the number of food insecure households and $G_{i}$ is the calorie intake deficiency for the $\mathrm{i}^{\text {th }}$ households. $\mathrm{G}_{i}$ was further expanded in a form:

$$
G_{i}=\left(\frac{Y_{i}-R}{R}\right)(7),
$$

where $Y$ and $R$ are as defined previously (above). The headcount ratio (HCR) is given as:

$$
\frac{M}{N} * 100 \% \text { (8), }
$$

where $N$ represents the number of households in the sample. The Surplus index (SI) is given by: 


$$
\frac{1}{M} \sum_{I=1}^{n}\left(\frac{R-Y_{i}}{R}\right)
$$

To determine the Daily Recommended Calorie Requirement or food needs of each farming household, the Ghana Statistical Service (GSS) and IFPRI (2000) standard of 2,900 kcal was used.

The households' composition or daily food requirement (daily calorie requirement) was estimated by first of all categorizing members of each household into different age groups based on the fact that different age groups have different calorie requirements. The daily energy (calorie) requirements of various compositions of the households were converted into adult equivalent using the equivalent scales as shown in Table 1.

Table 1. Recommended Daily Energy Intake and Equivalent Scale

\begin{tabular}{|c|c|c|}
\hline Age Category (years) & Average energy allowance per day & Equivalent Scale \\
\hline Children $(<6)$ & 1150 & 0.4 \\
\hline Children $(6-18)$ & 2250 & 0.7 \\
\hline Adults $(>18)$ & 2900 & 1.0 \\
\hline
\end{tabular}

Source: Ghana Statistical Service (2000).

Total household composition or calorie requirement was obtained by multiplying the total number of adult in each households by the recommended calorie requirement of $2,900 \mathrm{kcal}$ (i.e Total Number of adult $2900 \mathrm{kcal}$ ). The total food requirements for children were converted to adult equivalent. This was done by multiplying the total number of children below the age of six (6) years in each household by Recommended Daily Calorie Requirement of $2900 \mathrm{kcal}$ and conversion factor of 0.4 .

The total number of children between the ages of 6 to 18 years in each household was also multiplied by Recommended Daily Calorie Requirement of 2,900kcal and a conversion factor of 0.7 to obtain their adult equivalent. The total Daily Calorie Requirement for each household was obtained by summing up the requirement for the three age groups estimated above. The procedure was repeated for Recommended Daily Calorie Requirement of 2,260 kcal (FAO Ghana).

Households' daily food consumption (Daily Calorie Intake) was obtained from household own food production and purchases to supplement own food production. The data on actual food consumed (maize, rice, cassava, and plantain) by each household per week was obtained and converted into kilogram. The energy content of $1 \mathrm{~kg}$ of each foodstuff (maize, cassava, rice and plantain) was obtained from literature as showed in table 2.

Table 2. Cereal Equivalent Conversion Ratios

\begin{tabular}{|c|c|c|c|}
\hline Food Crop & Calorie/kg & Milling ratio & Maize equivalent ratio \\
\hline Maize & 3,590 & 0.85 & 1.00 \\
\hline Rice & 3,640 & 0.65 & 0.92 \\
\hline Cassava & 1,490 & & 0.40 \\
\hline Plantain & 1,350 & & \\
\hline
\end{tabular}

Source: Okigbo (1991) and Latham, (1969) [Compiled by Tayie and Lartey (2000). Nutrition and Food Science Department, University of Ghana, Legon]

The total quantity of each food (in kilogram) consumed was then multiplied by the energy content (e.g. total kilogram of cassava consumed per week ${ }^{*} 1,490 \mathrm{kcal}=$ total $\mathrm{kcal}$ of cassava consumed). This procedure was repeated for rice and plantain. However, due to processing and grinding losses, the quantity of maize consumed per week was multiplied by the energy content $(3950 \mathrm{kcal})$ and the milling ratio of 0.85 . The total kilocalories of maize, cassava, rice and plantain consumed by each household were summed up and divided by 7 to obtain Actual Daily Calorie Intake. 
Sample Size and Sampling Techniques. A multistage sampling technique was used to select the respondents that were interviewed. The first stage involves the selection of districts and municipalities from which respondents interviewed were selected. This was done using purposive sampling techniques where the districts and municipalities were grouped into forest and coastal areas. It was followed by writing the names of all the districts and municipalities in the forest areas on pieces of paper and randomly picking two districts or municipalities.

The second stage involved selection of communities and villages visited using purposive and simple random sampling. This was achieved with the help of the districts' MoFA directorates which grouped the communities into those which have functional Farmer Based Organization (FBO), extension contacts and those who do not have to give fair representation of different groups of farmers. Two communities each were selected from communities with functional FBO and extension contacts and those communities without FBO and extension contacts. The third and final stage was the selection of the farming households that were interviewed. Respondents were selected using simple random sampling, and data regarding their socio-economic characteristics, food availability, food accessibility and access to institutions were obtained for analysis.

In all 134 farming households were interviewed but 120 were selected for analysis after removing the questionnaires which were not properly administered. The households were selected from Two (2) districts and Eight (8) communities. In summary, food consumption data of 851 individuals in 120 households were used for the analysis.

Determining Factors Influencing Food Security Status of Farming Households. Logit regression model was used to determine factors influencing food security status of farming households in the forest parts of Central Region of Ghana and the variables included in the model are as follows:

Table 3. Variables Influencing Food Security Status of the Farming Households

\begin{tabular}{|c|c|c|c|}
\hline Variable & Descriptions & Measurement & $\begin{array}{c}\text { A priori } \\
\text { Expectation }\end{array}$ \\
\hline agehh & Age of household head & Years & $+1-$ \\
\hline genderhh & Gender of household head & Male $=1$, Female $=0$ & + \\
\hline farmsize & Farm size & Hectares & + \\
\hline off-farm & Engagement of off-farm activities & $\mathrm{Yes}=1, \mathrm{No}=0$ & +1 \\
\hline annincom & Annual income & GHS & + \\
\hline edu_Lev & Level of Education & $\begin{array}{c}\text { Primary }=1 \\
\text { JSS }=2 \\
\text { SSCE } / \text { WASSE }=3 \\
\text { Tertiary }=4\end{array}$ & + \\
\hline aces2crdit & Access to credit & $\mathrm{Yes}=1, \mathrm{No}=0$ & + \\
\hline Inownership & Land ownership & $\mathrm{Yes}=1, \mathrm{NO}=0$ & + \\
\hline ownprod & Quantity of Own production & $\mathrm{Kg}$ & + \\
\hline dep & Dependency ratio & Ratio & - \\
\hline Agesquared & Age Squared & Number & +- \\
\hline
\end{tabular}

Age of household head. The age of household head is expected to impact on his or her labour supply for food production (Babatunde et al., 2007). Young and energetic household heads are expected to cultivate larger farms compared to the older and weaker household head. It also determines the ability to seek and obtain off-farm jobs and income which younger household heads can do better. Arene and Anyaeji (2010), on the other hand, found older household heads to be more food secure than the younger household heads. Hence the expected effects of age of household head on food security could either be positive or negative.

Gender of Household Head. Gender of household head looks at the role played by the individuals in providing households' needs including acquisition of food. Household head can therefore be male or female. Therefore, gender of household head was coded as: 1 for males and 0 for females. Female headed households have higher dependency ratios which hinders household capacity to allocate labour to on-farm or other income-generating 
activities. Also female headed household tend to be older and have fewer years of education than male heads of household (FAO, 2012). The expected effect of this variable is positive.

Farm Size. Farm size is the total area of land cultivated to food and cash crop by households, measured in hectares. Positive relationship has been established between farm size and improvement in households' income and food security (Jayne et al., 2005; Deininger, 2003). The larger the farm size of the household, the higher the expected level of food production. It is, therefore, expected of a household with a larger farm size to be more food secure than a household with a smaller farm size, all things being equal. Hence the expected effect on food security is positive.

Engagement in off-Farm Activity. Off-farm activity is an additional work engaged in by household aside farming to supplement household income. Level of off-farm activity can influence households' food security but this can either be positive or negative depending on the level and gains from the activity (Babatunde et al., 2007). This is because engagement in an activity can bring in money thereby corroborating the food security situation of the household. On the other hand, if farmers spend more of their time on off-farm activities at the expense of working on their farm and particularly if the wage they earn does not commensurate with the forgone farm income, their food security situation could be worsened. Therefore, the expected effect on food security could be positive or negative.

Total Annual Income of Household. This refers to the sum of earnings of household from both off-farm and on-farm sources (Babatunde el al., 2007). According to Arene and Anyaeji (2010), the more household head engage in gainful employment, the higher he/she earns income and the greater the chances of being food secure. The income is expected to increase household's food production and access to more quantity and quality food. The expected effect on food security is, therefore, positive.

Level of Educational of Household Head. Education is a social capital which is expected to have positive influence on household food security. According to Shaikh (2007), the educated individuals have capacity to process and apply the information passed on to them. Lower educational levels impede access to better job opportunities in the labour market, and hamper more profitable entrepreneurship (FAO, 2012). An increase in female education not only increase their returns but also has the potential of reducing the fertility level of women, improve their productivity as well as contribute positively to the national growth ( Herzeet al., 1991).The expected effect of this variable on food security is positive.

Access to Credit. This is the ability of household to obtain credit both in cash and kind for either consumption or to support production. Consumption credit increases household's income on the short term basis and could increase the consumption basket of households (Babantunde et al., 2007). Production credit, on the other hand, when obtained on time could increase chances of household to acquire productive resources (seeds, fertilizers, pesticides and others) which will boost production and improve food situation in the house. Access to credit is therefore dummied as one (1) for households that obtained credit in the last year cropping season and 0 otherwise. The expected effect of access to credit on food security is positive.

Land Ownership. A farmer can own land either through inheritance or outright purchase. Jayne at al., (2005) noted that access to land is key strategy to reduce rural poverty and ensure food security. Evidence available showed that incident of food insecurity and poverty tends to be more severe in landless rural poor (Kyaw, 2009). Access to credit is therefore dummied as one (1) for households that obtained credit in the last year cropping season and 0 otherwise. The expected effect of access to credit on food security is positive.

Quantity of Own farm Production. This is the total quantity of food and cash crop produced by households from their own farm (measured in kilogram). Cash crops are included based on the fact that they can be sold and money realised from their sale could be used to purchase food for household consumption (Babaundeet al., 2007). The quantity of household own production increases the probability of food security (Quinoo, 2010; 2009; Pappoe, 2011). Therefore, the expected effect of this variable on food security is positive.

Farming Experience. This refers to the number of years household head has engaged in farming. All things being equal, an experienced household head is expected to have more insight and ability to diversify his or her production to minimize risk of food shortage. An 
experienced farmer is also expected to have adequate knowledge in pest and disease management as well as good knowledge of weather. Research findings revealed a positive relationship between farming experience and food security status (e.g., Felekeet al., 2003, Oluyoleet al., 2009). The expected effect of this variable on food security is, therefore, positive.

Dependency Ratio. This was measured as total household size divided by the number of individuals working to support the household. Owing to the scarcity of resources, an increase in household size especially the non-working members put pressure on consumption than production (Felekeet al.,2003). An increase in the number of non-working member of household or dependency ratio increases the food insecurity level of household (Ojogbo, 2010). The expected effect of this variable on food security is negative.

Age Squared. This was obtained by multiplying the age of household head by itself. The inclusion of this variable is as result of nonlinear relationship between age and food security. As age increases, the food security increases but at decreasing rate. Also as age increases, other factors such as farm experience may influence the food security status of households. Negative correlation between age squared and food security was revealed in the findings of Adenegan and Adewusi (2007). The positive effect of age and a negative effect of age squared imply as people get older the effect of age is lessoned. A positive effect of age and a positive effect of age squared means that as people get older the effect is age stronger. Therefore, expected effected of age is either positive or negative.

\section{EMPIRICAL RESULTS}

Socioeconomic Characteristics of Households. The socioeconomic characteristics of households presented in this study are: age, gender, marital status and household size. The data shows wide range of age groups, however close to half $(49.2 \%)$ of the respondents are above the age of 50 years. The data also revealed low (16.2\%) representation of the youth. Analysis of gender distribution of the households also revealed majority (85.8\%) of the household heads are males and female headed households being in the minority $(14.2 \%)$. The data revealed a wide range of household size (i.e., 16), with minimum household size of 2 and maximum of 18. The mean household size (7.06) was higher than the national of average 4 as stated GSS (2008).

Food Security Status of Farming Households in Forest Communities of Central Region of Ghana. Food security status of farming households in the study area is presented in the Table 4 . The result indicates majority $(60 \%)$ of farming households were food insecure. This implies that the study area is potentially food insecure since the number of food insecure households (72) is greater than food secure households (48). The mean food security index of food secure households was found to be 1.42 and food insecure households were also found to be 0.69 . The food insecurity gap implies that on average the food insecure households consumed $31 \%$ less than their daily calorie requirements whilst food secure households consumed $41 \%$ in excess of their daily calorie requirements. Per capital daily calorie requirement was estimated to be $2,275 \mathrm{kcal}$ which is lower than the national weighted average of 2,849 kcal (World Food Program, 2009; www.fao.org).

Table 4. Food Security Status of Farming Households in Forest Parts of Central Region

\begin{tabular}{|c|c|c|}
\hline Item Description & Food Secure & Food Insecure \\
\hline Percentage of Households & 40 & 60 \\
\hline Number of Households & 48 & 72 \\
\hline Mean (FSI) & 1.42 & 0.69 \\
\hline Standard deviation & 0.38 & 0.18 \\
\hline Food Insecurity gap/Surplus Index & 0.41 & 0.31 \\
\hline Per capita Daily Calorie Allowable & \multicolumn{2}{|c|}{$2,275.13$} \\
\hline
\end{tabular}


Categorization of Farmers Based on the Major Growing Crops and their Food Security Indices. Farming households in the study area were grouped based on the major types of crops they cultivated against their food security indices and presented in Table 5. Farming households were categorized as food crop, Tree crops and vegetable crop farming households. Though most of the farming households grow one food crop or the other, the categorization was based on the major source of income and food.

Table 5. Categorization of Farmers Based Major Growing Crop and Food Security Indices

\begin{tabular}{|c|c|c|c|c|c|c|c|}
\hline \multicolumn{8}{|c|}{ Categorization of farmers based on the food security indices and major crops grown } \\
\hline \multirow{2}{*}{\multicolumn{2}{|c|}{ Farmer Groups }} & \multicolumn{5}{|c|}{ Food Insecurity Indices of Farming Households } & \multirow{3}{*}{$\begin{array}{l}\text { Total } \\
\mathrm{N}=16\end{array}$} \\
\hline & & $0-0.25$ & $0.26-0.50$ & $0.51-0.75$ & $0.76-0.99$ & $\geq 1$ & \\
\hline \multirow[b]{2}{*}{ Food Crops } & Freg & 0 & 2 & 4 & 5 & 5 & \\
\hline & $\%$ & 0.0 & 1.7 & 3.3 & 4.2 & 4.2 & $13.3 \%$ \\
\hline \multirow{2}{*}{ Tree Crops } & Freq & 1 & 6 & 29 & 24 & 43 & $\mathrm{~N}=103$ \\
\hline & $\%$ & 0.85 & 5.5 & 24.2 & 20.0 & 35.8 & $85.8 \%$ \\
\hline \multirow{2}{*}{ Vegetables } & Freq & 0 & 0 & 1 & 0 & 0 & $\mathrm{~N}=1$ \\
\hline & $\%$ & 0.0 & 0.0 & 0.8 & $0.0 \%$ & 0.8 & $0.8 \%$ \\
\hline \multirow{2}{*}{ Total } & Freq & $\mathrm{N}=1$ & $\mathrm{~N}=8$ & $\mathrm{~N}=34$ & $\mathrm{~N}=29$ & $\mathrm{~N}=48$ & $\mathrm{~N}=120$ \\
\hline & $\%$ & $0.8 \%$ & $6.7 \%$ & $28.3 \%$ & $24.2 \%$ & $40.0 \%$ & $100 \%$ \\
\hline
\end{tabular}

Table 5 shows that, majority of the farming households $(85.8 \%)$ were tree crop farmers whilst food crop and vegetable farmers constitute $13.4 \%$ and $0.8 \%$, respectively. Among the food crop farmers, majority of them $(68.75 \%)$ were food insecure and $37.5 \%$ consumed $50 \%$ less their daily calorie requirements. The result also revealed $58.3 \%$ of tree crop farmers were food insecure and few $(6.8 \%)$ consumed $50 \%$ less their daily calorie requirements. The result also showed very low $(0.8 \%)$ representation of vegetable farmers which was food insecure.

Factors Influencing Food Security Status of Farming Households. To determine factors influencing food security status of farming households, socioeconomic characteristics of households were regressed on their food security indices and result presented in Table 6. The result showed four variables: total annual income, access to credit, dependency ratio and own food production as relevant in significantly influencing food security status of farming households in the study area. With the exception of dependency ratio which showed negative relationship with food security all the other variables had positive relationship with food security.

Table 6. Marginal Effects of Logit Regression Results of Factors Influencing Food Security Status Farming Households*

\begin{tabular}{|c|c|c|c|}
\hline Variables & Marginal effect & Standard Error & P-values \\
\hline Age of household head & -0.0594 & 0.0365 & 0.104 \\
\hline Farm size & -0.0028 & 0.0521 & 0.957 \\
\hline Engagement of off -farm activity & -0.1418 & 0.1688 & 0.401 \\
\hline Total annual income of household & $0.0001^{\star \star \star}$ & 0.00004 & 0.002 \\
\hline Level of education of household head & 0.1058 & 0.0799 & 0.185 \\
\hline Access to credit & $0.4785^{\star \star \star}$ & 0.1445 & 0.001 \\
\hline Land ownership & 0.1200 & 0.1514 & 0.428 \\
\hline Dependency ratio & $-0.1483^{\star \star \star}$ & 0.0529 & 0.005 \\
\hline Gender & -0.2879 & 0.1799 & 0.109 \\
\hline Own food production & $0.0257^{\star \star \star}$ & 0.0087 & 0.003 \\
\hline Agesquared & 0.0005 & 0.0003 & 0.132 \\
\hline
\end{tabular}

Source: Field Survey ${ }^{* * *}=$ significant @1\%

Number of Obs $=120$ Wald Chi2 (11) $=29.66$

Prob $>$ Chi2 $=0.0018$ Pseudo $R 2=0.4917$

Log pseudo likelihood $=-41.0503132$

* The marginal effects are used here (instead of the coefficients) as they denote the marginal changes of the dependent variables as a result of changes in the respective explanatory variables. Please note that the signs of the marginal effects are the same as those of the respective coefficients of the explanatory variables. 
Total annual Household Income. This variable has positive influence on food security status of farming households. The variable has the expected sign and is significant. This indicates the higher the income of households, the greater the probability of being food secure. This could be expected because, increased in income all things being equal, means increased access to food. The value of the marginal effect implies if households' income increase by One Ghana cedis (GHS 1.00), the probability of the household being food secure will be increased by 0.0001 , holding all other things constant, though negligible. This result is consistent with Babatunde et al., (2007); Adenega and Adewusi (2007); Arene and Anyaeji (2010) who revealed positive and significant relationship between household income and food security.

Access to Credit. This variable was found to have positive influence on food security status of households and met the a priori expectations. This could be expected since credit serves as consumption smoothing mechanism which gives households temporal relief against the effects of food insecurity. The result of the study implies that household that received credit had greater chances of being food secure compared to those who did not have credit, all things being equal. The value of the marginal effects indicates when a household obtains credit; the probability of that household to be food secure will be increased by 0.4785 . The result of the study is in line with the findings of Pappoe (2011), who found that access to credit improves the food security status of farming households among biofuel producers in the Central Region of Ghana.

Household's Dependency Ratio. Dependency ratio of the household was found to be significant and had inverse relationship with food security. This is expected because an additional increase in the number of non-working member of household increases the food requirement of households thereby reducing the probability of food security. The marginal effect of an additional increase in the number of non-working member of a household decreases the probability of the household being food secure by 0.1483 . This finding agrees with Ojogho (2010), who revealed that dependency ratio increases food insecurity level among arable farmers in Edo state of Nigeria. Etim and Patrick (2010) also found that dependency ratio increases the probability of households being poor which invariably reduces their food security status. Orewa and lyanbe (2010) also noted that an increase in the number of non-working member of household reduces the daily food calorie intake of rural and low-income urban households in Nigeria.

Quantity of Own Production. Quantity of own production was therefore found to be positive and significant. The positive sign of the variable indicates that the higher the output levels of household, the greater the likelihood of food security. The marginal effect of unit $(1 \mathrm{~kg})$ increase in quantity of household own production increases the probability of food security by 0.0257 . The result of this study is in line with earlier findings of Quinoo (2010), and Pappoe (2010) in the Central Region of Ghana. The finding of the study is also consistent with Babatunde et al., (2007), who obtained the same result among the rural farming households in the North -Central Nigeria. Further, Ojogho (2010) noted that lower output level of the household increases food insecurity status of arable farmers of Edo State, Nigeria.

Prevailing Food Insecurity Coping Strategies Used by Farming Households. The prevailing food insecurity coping strategies adopted by farming households in the study area to mitigate effects of food insecurity are presented in Table 7. The result from the table revealed the most widely used strategies by the farming households in the study area in order of importance are eating less preferred food, limiting size of the food consumed, skipping meal within a day and maternal buffering. This implies when households are faced with food shortage, the immediate strategy they adopt is to eat less preferred and less expensive food such as 'gari' and possibly 'kokonte'. As the food insecurity continues other strategies which are more severe are used such as reduce the quantity of food consume, skipping meal and parents (usually the mother) forgo their food to enable children have enough. 
Table 7. Food Insecurity Coping Strategies Adopted by Households

\begin{tabular}{|c|c|c|}
\hline Food Insecurity Coping Strategies & Mean Rank & Rank \\
\hline Eating less preferred food & 1.80 & $1^{\mathrm{st}-}$ \\
\hline Limiting size of food consumed & 3.51 & $2^{\text {nac }}$ \\
\hline Skipping meal within a day & 4.57 & $3^{\text {ra }}$ \\
\hline Maternal buffering & 5.66 & $4^{\text {tht }}$ \\
\hline Borrowing money to buy food & 5.75 & $5^{\text {tht }}$ \\
\hline Borrowing of food & 5.85 & $6^{\text {th- }}$ \\
\hline Collecting food from the wild or garden & 5.90 & $7^{\operatorname{th}-1}$ \\
\hline Sold Asset to buy food & 5.94 & $8^{\text {th- }}$ \\
\hline Travel to search for jobs & 6.03 & $9^{\text {th- }}$ \\
\hline
\end{tabular}

Other strategies adopted by households though with difficulties include borrowed money to buy food and borrowed food. These strategies were seen by households as loss of pride and those who practiced these strategies borrowed food or borrowed money from relatives and not from a neighbour for fear of being insulted when misunderstanding break up. Although forest areas are endowed with wild fruit and one would have expected household to resort to searching for wild fruit when faced with food shortage, it was one of the least practiced strategy by the farmers.

\section{CONCLUSIONS AND RECOMMENDATIONS}

The study seeks to examine the Food Security Status of Farming Households in the Forest Belt of the Central Region of Ghana. A multistage sampling technique was used to select the respondents that were interviewed. In all 134 farming households were interviewed but 120 were selected for analysis after removing the questionnaires which were not properly administered. The households were selected from eight communities in two districts. Food consumption data of 851 individuals in 120 households were used for the analysis. The study reveals that the majority of the farming households (60\%) were found to be food insecure. Further, the Binary Logit Model results reveal that an increase in household's income, having access to credit as well as increase in the quantity of own farm production improve the food security status of farming households in the Forest Belt of the Central Region of Ghana. However, holding all other factors constant, increases in non-working member of households worsens the food security status of farming households. Most of the food insecurity coping strategies adopted by household's are not severe and can only be used to avert the impact of food insecurity on a temporal basis.

The study provides the following policy recommendations. The government should broaden the pro-poor policies such as School Feeding, and the Livelihood Empowerment Against Poverty intervention programmes to cover large poor households. Next, education and sensitization of families regarding family planning should be intensified since higher dependency ratio worsens the food security status of farming households. Families should be educated on the need to give birth to number of children they can comfortably cater for.

Provision of input such as weedicides, fertilizer, improves seeds and others will motivate farming households and also increase their productivity, especially those in the coastal areas would be a step in the right direction. This will increase the volume of food production. This could be done through selling of input at subsidized rate to farmers on credit by MOFA and allow farmers pay in kind with their farm produce. This will serve as source of market to farmers and also contribute to the performance of the government's buffer stock program.

Food insecurity coping strategies adopted by the farming households have short term effect. Therefore, there is the increase the volume of food production as well as improve on access to income generating activities that are more sustainable. The research was conducted for the Forest Belt of the Central Region of Ghana; hence the results may not be representative of the food security status of farming households across the country. Therefore, extending this study to cover other Regions of the country is a useful avenue for future research. 


\section{REFERENCES}

[1] Adenegan, K.O. and Adewusi, O.A. (2007). Determinants of Food Security Status of Rural Households Living With HIV/AIDS in Southwestern Nigeria. African Journal of Biomedical Research, Vol. 10: $9-18$.

[2] Arene, C. J. and Anyaeji, J. (2010).Determinants of Food Security among Households in Nsukka Metropolis of Enugu State, Nigeria. Pakistan Journal of Social Sciences 30(1): 9-16.

[3] Arimah, B. C. (2004). Poverty Reduction and Human Development in Africa. Journal of Human Development, 5(3): 399-415.

[4] Babatunde, R. O., Omotosho, O. A. and Sholotan, O.S. (2007). Factors Influencing Food Security Status of Rural Farming Households in North Central Nigeria. Agric. J., 2(3): $351-357$.

[5] Baro, M. and Deubel, T. (2006). Persistent Hunger: Perspectives on Vulnerability, Famine and Livelihood Security In Sub-Saharan Africa. Annual Review of Anthropology 35, PP. 521-538.

[6] Bokeloh, G., G. M. Gerster-Bentaya, S. L. Weingärtner, Rottenburg (2009): Achieving Food and Nutrition Security. Actions to Meet the Global Challenge. A Training Course Reader. Internationale Weiterbildung $\mathrm{GmbH}$ Capacity Building International (InWEnt), Germany.

[7] Boko M, Niang, I., Nyong, A., Vogel. C., Githeko, A., Medany, M., Osman-Elasha, B., Tabo, R., Yanda, P., Parry, M.L., Canziani, O., F., Palutikof, J., P., van der Linden, P., J, Hanson, C. E. (eds) Climate Change (2007):Impacts, adaptation and vulnerability. Contribution of Working Group II to the Fourth Assessment Report of the Intergovernmental Panel on Climate Change. Cambridge University Press, Cambridge, UK, pp. 433-467.

[8] Cruz, L. (2010). Responsible Governance of Land Tenure. An Essential Factor for the Realization of the Right to Food. Land Tenure Working Group Discussion Paper 15, FAO. Rome.

[9] Datt, G., K. Simler, S. Mukherjee, and Dava, G. (2000). Determinants of Poverty in Mozambique 199697 (FCND Discussion Paper. No.78). International Food Policy Research Institute: Washington, DC.

[10] Dessy, S. E., Woudou, J. and Ouellet, I (2006), "Understanding the Persistent Low Performance of African Agriculture", CIRPEE Working Paper 06-22.

[11] Etim, N.A. and Solomon V.A. (2010). Determinants of rural poverty among broiler farmers in Uyo, Nigeria: Implications for rural household food security. Journal of Agriculture and Social Sciences 6: 24-28.

[12] Feleke, S., Kilmer, R. L. and Gladwin, C. (2003). Determinants of Food Security in Southern Ethiopia. A selected paper presented at the 2003 American Agricultural Economics Association meetings in Montreal. Canada. Retrieved on 12th December, 2005 from http://ageconsearch.umn.edu/bit stream/22010/1/sp03fe02.pdf

[13] Fofack, H. (2002). The Nature and Dynamics of Poverty Determinants in Burkina Faso in the1990s (Poverty Working Paper 2847). World Bank: Washington, DC; http://econ.worldbank.org/files/15281_wps2847.pdf

[14] Food and Agricultural Organization of United Nations, FAO, (2012).Gender Inequalities in Rural Employment in Ghana An overview.Prepared by the Gender, Equity and Rural Employment Division FAO. Rome, Italy.

[15] Food and Agriculture Organization of the United Nations, FAO, (1996).Report of the World Food Summit. Rome, Italy.

[16] Food and Agriculture Organization of United Nations, FAO, (2002).Safe and Nutritious Food for Consumer.World Food Summit, Rome, Italy.

[17] Geda, A., de Jong, N., Mwabu, G. and Kimenyi, M. (2001). Determinant of Poverty in Kenya: A Household Level Analysis (Working Paper). Institute of Social Studies: The Netherlands.

[18] Ghana Statistical Service, (2008).Ghana Living Standards Survey, Report of the Fifth Round (GLSS 5). Accra, Ghana.

[19] Ghana Statistical Service, GSS, (2000). Poverty Trends in Ghana in the 1990s. Accra, Ghana. 
[20] Ghana Statistical Service, GSS, (2012). Revised Gross Domestic Product 2011. National Accounting. Accra, Ghana.

[21] Greer, J. and Thorbecke, E. (1986). A Methodology for Measuring Food Poverty Applied to Kenya. Journal of Development Economics, 24: 59-74.

[22] Gregory, P., Ingram, J. S. I., Brklacich M, (2005). Climate Change and Food Security. Philosophical Transactions of the Royal Society B-Biological Sciences, 360 (1463): 2139-2148.

[23] Grootaert, C. (1997). The Determinants of Poverty in Co^te d'Ivoire. Journal of African Economies 6:169-196.

[24] Haile, H. K., Z. G. Alemu and G Kudhlande (2005).Causes of Household Food Insecurity in Koredejaja Pleasant Association, Orimiza Zone, Ethiopia. Working Agricultural Economics, University of Frees.

[25] Helen, H. J. (2002): Food Insecurity and the Food Stamp Programme. American Journal ofAgricultural Economics, 84(5): 1215-1218.

[26] Herz, B.K., Subbarao, M.H. and Raney, L. (1991) 'Letting Girls Learn: Promising Approaches In Primary and Secondary Education', World Bank Discussion Paper 133, World Bank, Washington, DC.

[27] International Food Policy Research Institute, IFPRI, (2000). Women, the Key to Food Security. Washington, DC.

[28] International Fund for Agricultural Development, IFAD, and Food and Agricultural Organization, FAO, (2010). Jatropha: A Smallholder Bioenergy Crop.The Potential for Pro-Poor Development. Integrated Crop Management 8: PP. 1-12

[29] Jayne, T.S., Marther, D. and Mghenyi, E (2005). Smallholder Farming in Difficult Circumstances: Policy Issues for Africa in IFPRI (International Food Policy Research Institute): The future of small farms:Proceedings of a Research Workshop. PP.103123. Wye, UK, Washington, DC.

[30] Jrad, S., Nahas, B., Baghasa, H. (2010).Food Security Models.Ministry of Agriculture and Agrarian Reform, National Agricultural Policy Center. Policy Brief No 33. PP.32. Syrian Arabic Republic.

[31] Khatri-Chhetri, A. and Maharjan, K. L. (2006): Food Insecurity and Coping Strategies in Rural Areas of Nepal. A Case Study of Dailekh District in Mid Western Development Region. Journal of International Development and Cooperation, 12 (2): 25-45.

[32] Kuwornu, J. K. M., Mensah-Bonsu, A., Ibrahim, H. (2011). Analysis of Foodstuff Price Volatility in Ghana: Implications for Food Security. European Journal of Business and Management 3 (4.): 100-118.

[33] Kyaw, D. (2009). Rural Households' Food Security and Coping Strategies to Food Insecurity in Myanmar.Institute of Developing Economies, Japan External Trade Organization.R. F. Series No. 444. PP. 78.

[34] Ministry of Food and Agriculture, MoFA, (2007).Food and Agriculture Sector Development Policy (FASDEP II). Accra, Ghana.

[35] Ministry of Food and Agriculture, MoFA, (2010a).Agriculture in Ghana. FACTS AND FUGURES (2009). pp. 53, Accra, Ghana.

[36] Misselhorn, A. (2005). What Drives Food Insecurity in Southern Africa? A MetaAnalysis of Household Economy Studies. Global Environmental Change 15: 33-43.

[37] Moharjan, K. L. and- Chhetri, A. K. (2006). Household Food Security in Rural Areas of Nepal: Relationship between Socio-Economic Characteristics and Food Security Status. Paper Presented at the International Association of Agricultural Economists' Conference, Gold Coast, Australia.

[38] Ojogho, O. (2010): Determinants of Food Insecurity among Arable Framers in Edo State, Nigeria. Agricultural Journal5(3): 151-156.

[39] Oldewage-Theron, W., Dicks, E., and Napier, C. (2006). Poverty, Household Food Insecurity and Nutrition: Coping Strategies in an Informal Settlement in the Vaal Triangle, South Africa. Public Health 120, 795-804.

[40] Oluyole, K. A., Oni, O. A., Omonona, B. T. andAdenegan, K. O. (2009).Food Security among Cocoa Farming Households ofOndo State, Nigeria.ARPN Journal of Agriculture. and Biological. Sciences 4:7-13. 
[41] Omotesho, O. A., and Muhammad-Lawal, A. (2010): Optimal Food Plan for Rural Households' Food Security in Kwara State, Nigeria: The Goal Programming Approach. Journal Agriculture, Biotechnology and Sustainable Development, 2(1): 007-014. Available online http://www.academicjournals.org/JABSD.

[42] Orewa, S. I., and lyangbe, C. (2010). The Struggle against Hunger: The Victims and the Food Security StrategiesAdopted in Adverse Condition. World Journal of Agricultural Science 6 (6): 740-745.

[43] Pappoe, P. (2011). Effect of Biofuel Production on Household Food Security in the Central Region of Ghana. Unpublished Thesis submitted to the Department of Agricultural Economics and Agribusiness, University of Ghana.

[44] Pindyck, S. and Rubinfeld, L (1981).Econometric Models and Economic Forecasts, Second Edition. McGraw-Hill, New York.

[45] Pinstrup-Andersen, P. (2009). Food Security: Definition and Measurement.Springer Science +Business Media B.V. \& International Society for Plant Pathology. Food Science, 1:5-7.

[46] Quaino, M. E. (2010). Food Security Implications of Women Farmers' Participation in Biofuel Crop Production in the Gomoa District. Unpublished MPhil Thesis submitted to the Department of Agricultural Economics and Agribusiness, University of Ghana, Legon.

[47] Rosenzweig, C., Iglesias, A., Yang, X., Epstein, P., Chivian, E. (2001).Climate Change and Extreme Weather Events.Implications for Food Production, Plant Diseases and Pests. Global Change and Human Health 2: 90-104.

[48] Salama, A; Kamara, A. B. and Brixiova, Z. (2010). Smallholder Agriculture in East Africa: Trends, Constraints and Opportunities, Working Papers Series $N^{\circ} 105$, African Development Bank, Tunis, Tunisia.

[49] Sen AK. (1976). Poverty: An Ordinal Approach to Measurement. Econometrica 43: 153-169.

[50] Shaikh, F. M. (2007). Determinants of Household Food Security and Consumption Pattern in Rural Sindh: Non-Separable Agriculture Household Model. IUB Journal of Social Sciences and Humanities, 5(2): 18-39.

[51] Smith, L., Obeid, A., Jensen, H. (2000). The Geography and Causes of Food Insecurity in Developing Countries. Agricultural Economics 22: 199-215.

[52] Trostle, R. (2008). Global Agricultural Supply and Demand: Factors Contributing To the Recent Increase in Food Commodity Prices. WRS-0801. Washington DC: USDA.

[53] Tweeten, L. (1997). Food Security. In L.G. Tweeten and D.G. McClelland (eds).

[54] United Nation Development Programme, UNDP, (1992).The Human Development Index- going Beyond Income. htt//www.hdrstas.undp.org/country-fact-sheet/cty-fsETH.htm

[55] United Nation Development Programme, UNDP, (1997). Human Development Report, Oxford University Press, New York.

[56] Valdés, A. Foster, W., Anríquez, G., Azzarri, C., Covarrubias, K., Davis, B., DiGiuseppe, S., Essam, T., Hertz, T, Paula de la, A., O, Quiñones, E., Stamoulis, K., Winters, P., Zezza, A., (2010). A Profile of the Rural Poor.A Background Paper for IFAD Rural Poverty Report.IFAD. Rome. http://www.ifad.org/rural/rpr2010/background/2.pdf

[57] Wodon, Q., Tsimpo, C. and Coulombe, H. (2008). Assessing the Potential Impact on Poverty of Rising Cereal Prices. The World Bank. Human Development Network. Working Paper 4740.

[58] World Bank (1986). Poverty and Hunger: Issues and Options for Food Security in Developing Countries. Word Bank, Washington DC.

[59] World Bank (2008). The Growth Report: Strategies for Sustained Growth and Inclusive Development. Washington, DC.

[60] World Food Programme, WFP, (2009). Comprehensive Food Security and Vulnerability Analysis. Accra, Ghana. PP. 168. www.fao.org 